\title{
PENGARUH MODEL ELICITING ACTIVITIES TERHADAP KREATIVITAS MATEMATIS PADA SISWA KELAS VIII PADA SATU SEKOLAH DI KAB. KARAWANG
}

\author{
Oleh: \\ Rafiq Zulkarnaen \\ Pendidikan Matematika FKIP UNSIKA \\ rzulkarnaen@gmail.com
}

\begin{abstract}
ABSTRAK
Penelitian ini difokuskan untuk mengetahui seberapa besar pengaruh pembelajaran matematika menggunakan model eliciting activities terhadap kreativitas matematis siswa kelas VIII. Metode eksperimen digunakan dalam penelitian ini, dengan desain one-sampel group design. Populasi adalah seluruh siswa kelas VIII di satu sekolah di Kabupaten Karawang, dengan sampel sebanyak 30 siswa melalui teknik sampling acak dengan pengembalian. Hasil penelitian diperoleh model eliciting activities memberikan pengaruh cukup kuat terhadap kreativitas matematis, yakni sebesar $64 \%$, faktor lainnya disebabkan oleh variabel moderat.
\end{abstract}

Kata Kunci : Model eliciting Activities, Kreativitas Matematis

\begin{abstract}
This study is focused to determine how much influence the learning of mathematics using the model eliciting activities for students of class VIII mathematical creativity. Experimental method used in this study, with a one-sample design group design. The population is all eighth grade students at a school in Karawang, with a sample of 30 students through random sampling with replacement technique. The results obtained by the model eliciting activities provide a strong enough influence on mathematical creativity, which amounted to $64 \%$, other factors caused by moderate variable.
\end{abstract}

Keywords: Activities eliciting models, Mathematical Creativity

\section{PENDAHULUAN}

Kreativitas adalah suatu produk dari sebuah ide, sebuah ide dihasilkan melalui proses berpikir yang melibatkan aktivitas kognitif. Proses demikian disebut sebagai proses berpikir kreatif. Setiap siswa mempunyai potensi untuk kreatif. Kreativitas siswa akan tumbuh apabila dilatih melakukan eksplorasi, inkuiri, penemuan dan memecahkan masalah (Ruseffendi, 1991: 239). Model Eliciting Activities adalah suatu pendekatan pembelajaran yang melibatkan siswa untuk terlibat aktif dalam 
menkonstruksi pengetahuan matematika melalui situasi masalah yang bersifat terbuka, dan siswa menyelesaikan masalah tersebut melalui iterative-modeling atau translasi dari satu representasi ke representasi matematis lainnya. Siswa akan menkonstruksi pengetahuannya melalui conceptual system dan representation system. (Less dan Doerr, 2003: 27).

Berdasarkan uraian tersebut di atas, penelitian ini bertujuan untuk mengetahui pegaruh pembelajaran matematika menggunakan model eliciting activitie terhadap kreativitas matematis pada siswa kelas VIII.

\section{STUDI LITERATUR}

\section{Kreativitas Matematis}

Chamberlin dan Moon (2005: 38) mengemukakan, kreativitas matematis mungkin ada ketika solusi tidak standar dibuat untuk memecahkan masalah yang dapat diselesaikan dengan algorithma penyelesaian. Dengan kata lain, kreativitas matematis dapat dilihat sebagai penciptaan algoritma, strategi atau bahkan pendekatan alternatif untuk masalah standar.

Kreativitas mengandung orisinalitas atau kebaruan dan kebaruan merupakan ciri khas untuk mengidentifikasi produk kreatif (Fetterly, 2010: 12). Originalitas adalah kemampuan untuk menghasilkan ide-ide yang tidak umum atau luar biasa, menyelesaikan masalah dengan cara yang tidak umum atau tidak baku atau menggunakan sesuatu atau memanfaatkan situasi dengan cara yang tidak umum (Evans, 1991: 41), ketika siswa meniru jawaban atau prosedur solusi tidak dilihat sebagai originalitas (Lithner, 2008: 260).

Ciri-ciri orisinil adalah mampu melahirkan ungkapan yang baru dan unik, memikirkan cara yang tidak lazim untuk mengungkapkan diri, mampu membuat kombinasi yang tidak lazim dari bagian-bagian atau unsur-unsur. Keterampilan ini ditunjukan oleh perilaku siswa seperti: memikirkan masalah-masalah atau hal-hal yang tidak pernah terpikirkan oleh orang lain, mempertanyakan cara-cara yang lama dan berusaha memikirkan cara-cara yang baru, memilih a-simetri dalam menggambar atau membuat disain, memiliki cara berpikir yang lain dari yang lain, mencari pendekatan yang baru, setelah membaca atau mendengar gagasan-gagasan bekerja untuk menemukan penyelesaian yang baru, lebih senang mensintesis daripada menganalisis situasi. (Ratnaningsih, 2007: 34).

Silver (1997: 750) mengemukakan, kreativitas berkaitan erat dengan pengetahuan mendalam yang bersifat fleksibel terkait konten matematika. Pengetahuan matematika yang komprehensif sangat penting untuk pengembangan kreativitas matematis, pengetahuan akan konten matematika membantu siswa untuk membuat hubungan antara konsep yang berbeda dan jenis informasi yang diberikan. Oleh 
karena itu, siswa yang memiliki karakteristik akurat dalam menyelesaikan masalah yang diajukan dan mencetuskan banyak gagasan, jawaban, penyelesaian masalah, atau pertanyaan; memberikan banyak cara atau saran untuk melakukan berbagai hal; selalu memikirkan lebih dari satu jawaban lebih mampu berpikir kreatif dalam tugas-tugas matematika baru dengan menyediakan solusi asli dan bermakna (Kattou et.all, 2011: 1080).

\section{Model Eliciting Activities}

Secara epistimologi Model Eliciting Activities (disingkat MEA) memuat tiga kata, yakni model artinya suatu upaya penciptaan replika dari suatu fenomena, eliciting artinya membangun dan activities artinya aktivitas. Sehingga MEA adalah suatu aktivitas untuk membangun suatu model, dalam konteks ini adalah aktivitas pembelajaran yang dapat membangun model matematis.

Model adalah sistem konseptual internal dan eksternal yang digunakan untuk membangun, menjelaskan, atau menjelaskan pengalaman matematis, sehingga memungkinkan sistem lainnya dapat dimanipulasi atau diprediksi. Jadi, sebuah model matematika berfokus pada karakteristik struktural dari sistem yang relevan. Komponen internal mengacu kepada konstruksi atau sistem konseptual, dan komponen internal mengacu kepada media representasi. Siswa berusaha memahami matematika menggunakan sistem konseptual melalui representasi yang saling berkaitan satu dengan yang lainnya. Representasi itu adalah menulis simbol, diagram atau gambar, konkrit model, bahasa lisan atau verbal, pengalaman berbasis metaphor. (Lesh dan Doerr, 2003: 10).

MEA adalah kegiatan yang mendorong siswa untuk menciptakan dan menguji model matematis. Siswa diberikan masalah yang terbuka yang dirancang untuk menantang siswa untuk memecahkan kompleks melalui konstruksi model dari masalah di dunia nyata. Less dan Doerr (2002: 23) mengemukakan bahwa prinsip dalam pembelajaran menggunakan MEA, yakni:

a) Prinsip pengembangan Model. Masalah didesain sedemikian rupa yang dapat menuntut siswa untuk menciptakan model matematis yang meliputi elemen, relasi dan hubungan, pola atau aturan diantara elemen tersebut.

b) Prinsip realitas. Masalah harus bermakna dan relevan dengan siswa dan didasarkan pada data nyata atau sedikit dimodifikasi. Solusinya harus "nyata" dan bermakna dalam kehidupan sehari-hari siswa.

c) Prinsip penilaian sendiri. Siswa harus mampu menilai diri sendiri terkait kegunaan dan model penyelesaian masalah yang diajukan. Pernyataan masalah harus memungkinkan siswa untuk menilai diri sendiri.

d) Prinsip pendokumentasian Model. Siswa harus mampu mengungkapkan dan mendokumentasikan proses berpikir mereka dalam solusi mereka. Kegiatan ini harus mendorong refleksi berpikir siswa (metakognisi). 
e) Prinsip kegunaan dan berbagi model yang dihasilkan. Solusi yang dibuat oleh siswa digeneralisasikan atau mudah disesuaikan dengan situasi serupa lainnya. Model ini harus mewakili secara umum berpikir bukan solusi spesifik untuk konteks tertentu. Prinsip ini juga memastikan bahwa siswa dapat mengkomunikasikan dengan cara yang dimengerti jelas yang memungkinkan model yang dihasilkan dapat digunakan oleh siswa.

f) Prinsip Efektivitas. Model yang dihasilkan sesederhana mungkin, proses berpikir metaphor untuk menafsirkan masalah lain dengan struktur dasar yang sama.

Ilustrasi pembelajaran menggunakan Model Eliciting Activities (MEA) sebagai berikut: Pertama, guru membaca sebuah artikel koran, kegiatan ini dimaksudkan untuk mengembangkan konteks siswa; Kedua, siswa menanggapi permasalahan yang mungkin muncul berdasarkan artikel tersebut; Ketiga, setelah siswa dibagi kedalam kelompok kemudian guru membaca pernyataan masalah yang terkait dengan artikel koran tersebut dalam langkah ini guru harus memastikan setiap kelompok mengerti permasalaan apa yang diajukan, dan siswa berusaha memecahkan masalah. Keempat: setelah beberapa iterasi dari solusi, siswa menyajikan model atas pertanyaan yang diajukan serta solusi penyelesaiannya. (Chamberlin, 2002: 10).

\section{METODE PENELITIAN}

Penelitian ini bertujuan untuk mengetahui pengaruh model eliciting activities terhadap kreativitas matematis siswa kelas VIII menggunakan metode eksperimen dengan desain one sample pretes-postes design. Populasi penelitian adalah seluruh siswa kelas VIII di satu sekolah. Jumlah sampel sebanyak 30siswa mendapatkan perlakuan pembelajaran menggunakan model eliciting activities. Adapun teknik sampling yang digunakan secara acak dengan pengembalian.

Instrumen penelitian yang digunakan adalah seperangkat soal uraian sebanyak lima soal disesuaikan dengan indikator kreativitas matematis. Pedoman penskoran sebagai berikut: 
Tabel. 1

Skoring Kreativitas bentuk Multiple Solution Task

\begin{tabular}{|c|c|c|c|c|}
\hline & Fluency & Flexibility & Originality & Creativity \\
\hline \multirow{4}{*}{ 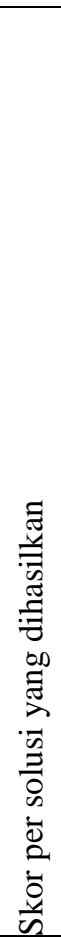 } & \multirow{4}{*}{1} & $\begin{array}{l}\qquad F l x_{i}=10 \\
\text { untuk } \\
\text { pertama }\end{array}$ & \begin{tabular}{l}
\multicolumn{3}{c}{$O r_{i}=10$} \\
$P \quad<\quad 15 \%$ atau \\
solusi \\
berdasarkan \\
algotritma umum
\end{tabular} & \multirow{4}{*}{$C r_{i}=F l x_{i} \times O r_{i}$} \\
\hline & & $\begin{array}{l}\qquad F l x_{i}=10 \\
\text { solusi yang } \\
\text { berbeda dengan } \\
\text { sekumpulan solusi } \\
\text { yang lainnya }\end{array}$ & \begin{tabular}{ll}
\multicolumn{3}{c}{$\mathrm{Or}_{i}=1$} \\
$15 \%<P<40 \%$ \\
atau $\quad$ hanya \\
sebagian $\quad$ solusi \\
berdasarkan \\
algoritma \\
penyelesaian
\end{tabular} & \\
\hline & & $\begin{array}{l}\qquad F l x_{i}=1 \\
\text { Strategi yang sama } \\
\text { tetapi dengan } \\
\text { representasi yang } \\
\text { berbeda }\end{array}$ & \begin{tabular}{l}
\multicolumn{2}{c}{$O r_{i}=0,1$} \\
$P \quad>\quad 40 \%$ atau \\
berdasarkan \\
algoritma \\
penyelesaian atau \\
solusi \\
konvensional
\end{tabular} & \\
\hline & & $\begin{array}{l}\qquad F l x_{i}=0,1 \\
\text { Strategi dan } \\
\text { representasi yang } \\
\text { sama }\end{array}$ & & \\
\hline
\end{tabular}

(Sumber : Lev dan Leikin, 2013: 1206)

Keterangan : $P=\left(\frac{M_{j}}{n}\right) \times 100 \%$ dengan $M_{j}$ banyaknya siswa menggunakan strategi penyelesaian yang sama.

\section{HASIL DAN PEMBAHASAN}

Hasil pengolahan data kreativitas matematis sampel penelitian tersaji pada Tabel.2 berikut.

Tabel.2

Hasil Pengolahan Data

\begin{tabular}{|c|c|c|c|c|c|c|c|c|}
\hline & \multicolumn{2}{|c|}{ Fluency } & \multicolumn{2}{c|}{ Flexibilty } & \multicolumn{2}{c|}{ Original } & \multicolumn{2}{c|}{ Creative } \\
\cline { 2 - 9 } & $\bar{x}$ & $s$ & $\bar{x}$ & $s$ & $\bar{x}$ & $s$ & $\bar{x}$ & $s$ \\
\hline Pretes & 0,38 & 4,57 & 2,34 & 4,57 & 0,98 & 1,22 & 13,14 & 3,12 \\
\hline Postes & 0,68 & 3,12 & 8,40 & 1,23 & 6,32 & 0,56 & 23,4 & 2,00 \\
\hline
\end{tabular}

Mengacu Tabel.2 nampak bahwa model eliciting activities (MEA) memberikan pengaruh terhadap kreativitas matematis siswa. Namun demikian, pada aspek original nampak bahwa dalam menyelesaikan soal yang diajukan, siswa masih 
mengunakan imitative reasoning. Mereka lebih cenderung menghapal algortima penyelesaian, mengingat jawaban yang lengkap, pilihan strategi didasarkan pada identifikasi dari sumber buku teks seperti contoh, definisi, teorema, atuan, fakta atau situasi lain yang ada relevansi dengan tugas yang diberikan, implementasi strategi dilakukan dengan menyalin prosedur atau fakta dari situasi permasalahan yang telah diidentifikasi.

Aspek keluwesan (flexibility) terjadi peningkatan signifikan, peningkatan ini merupakan efek dari pembelajaran matematika menggunaan MEA. Dalam pembelajaran menggunakan MEA memiliki karakteristik iteratif modeling, siswa melakukan translasi dari satu representasi ke representasi matematis lainnya. Proses translasi representasi tersebut diduga menjadi elemen kunci keluwesan siswa dalam menyelesaikan soal yang diberikan. Selain itu juga, MEA memberikan kesempatan kepada siswa untuk saling berinteraksi dalam dan antar kelompok untuk saling berdiskusi, menjelaskan, proses inkuiri dan discovery situasi masalah yang menyebabkan terjadinya kematangan pengetahuan sebagaimana pendapat teori kostruktivis sosial Vygotsky.

Dalam perpektif pembelajaran menggunakan MEA, model merupakan komponen kunci yang mendorong siswa untuk menciptakan dan menguji model matematis. Siswa diberikan masalah yang terbuka yang dirancang untuk menantang siswa untuk memecahkan kompleks melalui konstruksi model dari masalah di dunia nyata. siklus model yang berbeda menandakan cara berpikir yang berbeda terkait informasi masalah, tujuan, kemungkinan perbedaan strategi penyelesaian yang melibatkan serangkaian siklus modeling, heuristik dan strategi yang bertujuan untuk membantu siswa menemukan cara yang produktif untuk beradaptasi, memodifikasi, dan memperbaiki ide-ide yang mereka miliki.

Hasil pengolahan statistika lainnya dalam hal size-effect variabel terikat disebabkan oleh variabel bebas diperoleh sebesar 64\% dengan kategori cukup kuat, sedangkan $36 \%$ lainnya disebabkan faktor variabel moderat, misalnya: karakter guru, learningstyle siswa, status sekolah, maturation, dan lain sebagainya. Dalam penelitian ini faktor variabel moderat tidak dianalisis secara lebih mendalam.

\section{KESIMPULAN}

Berdasarkan hasil penelitian dan pembahasan sebagaimana dikemukakan sebelumnya maka diperoleh simpulan bahwa model eliciting activities memberikan pengaruh cukup kuat terhadap kreatifitas matematis siswa kelas VIII 


\section{DAFTAR PUSTAKA}

Chamberlin, S.A. (2002). How does the problem based learning approach compare to the model-eliciting activity approach in mathematics? [online] diakses di http://www.uwyo.edu/wisdome/_files/documents /chamberlin_ coxbill.pdf (3 Maret 2015)

Chamberlin, S. A., \& Moon, S. M. (2005). Model-eliciting activities as tool to develop and identify creativity gifted mathematicians. Journal of Secondary Gifted Education, 17(1), 37-47.

Evans, J.R. (1991). Creative thinking in the decision and management sciences. USA: South-Western Publishing Co.

Fetterly, J.M. (2010). An exploratory study of the use of problem-possing approach on pre-service elementaryteacher's mathematical creativity, beliefs, and anxiety. The Florida State University: Electronic Theses, Treatises and Dissertations

Kattou, M et.all. (2011). Does mathematical creativity differentiate mathematical ability?. Proceedings of the Seventh Congress of the European Society for Research in Mathematics Education, 9 - 13 February 2011 Rzeszôw, Poland

Lesh dan Doerr (2002). Beyond constructivism: model and modeling perspective on mathematical problem solving, learning, and teaching. New Jersey: Marwah

Lithner, J. (2008). A research framework for creative and imitative reasoning. Educational Studies in Mathematics, 67(3), 255-276. [online] diakses di http://snovit.math.umu.se/Forskning/Didaktik/Rapportserien/060705B4D2.pd $\mathrm{f}$

Ratnaningsih, N. (2007). Pengaruh pembelajaran kontekstual terhadap kemampuan berpikir kritis dan kreatif matematik serta kemandirian belajar siswa sekolah menengah atas. Disertasi Program Studi Pendidikan Matematika Sekolah Pascasarja Universitas Pendidikan Indonesia, Tidak Diterbitkan

Ruseffendi, E.T. (1991). Pengantar kepada Membantu Guru Mengembangkan Kompetensinya dalam Pengajaran Matematika untuk Meningkatkan CBSA. Bandung: Tarsito

Silver, E.A. (1997). Fostering creativity through Instruction rich in mathematical problem solving and problem Posing. Zentralblatt für Didaktik der Mathematik 29 (3), 75-80. 